\title{
AN INVESTIGATION INTO THE EXTENT AND CHALENGES OF ASSESSING STUDENTS' SPEAKING SKILLS IN SELECTED SECONDARY SCHOOLS: THE CASES OF WOLAYITA ZONE, ETHIOPIA
}

\author{
Mebratu Mulatu Bachore ${ }^{1}$, Amare Satenaw ${ }^{2}$ \\ College of Social Sciences and Humanities, Hawassa University, Ethiopia', Boditi Secondary \\ School, Boditi, Ethiopia?
}

\author{
mebratumulatu@gmail.com ${ }^{1}$, amaresatenaw12@gmail.com²
}

First draft received: 03 June 2018 Accepted: 31 July 2018 Final proof received: 30 August 2018

\begin{abstract}
The main objective of this study was to investigate the assessment of students' speaking skill in some selected preparatory schools. It was a descriptive survey. The data were collected from teachers and students using questionnaire, interview, and classroom observations. Yemane' (1996) formula was used to determine the sample size. Accordingly, 254 students were selected as samples using simple random sampling technique. Six English language teachers who teach grade 11 students were selected using availability sampling technique. The data collected via questionnaire were filled into SPSS and then, different statistical analyses such as frequency and percentage were computed from the data in the SPSS. The results of statistical analysis were presented in tables and pie chart. Besides, data obtained from interview were transcribed and categorized according to related themes. The study revealed that English teachers assess speaking skills of their students at different times. But, it was noted that most teachers assess speaking skill during speaking lessons only. Regarding the frequency, many EFL teachers assess their students always; however, it was disclosed that there are teachers who assess their students speaking once in a month and even in a semester. The findings of the study also disclosed that different factors such as lack of adequate time, lack of sufficient material, large number of students per class, and teacher's inappropriate way of assessing speaking skill affect the assessment of speaking skill.

Keywords: Speaking Skills, Assessment, Challenges
\end{abstract}

To cite this paper (in APA style):

Bachore, M. M., \& Satenaw, A. (2018). An investigation into the extent and challenges of assessing students' speaking skills in selected secondary schools: The cases of Wolayita Zone, Ethiopia. International Journal of Education, 11(1), 78-86. doi: http://dx.doi.org/10.17509/ije.v11i1.12165.

\section{INTRODUCTION}

English, as one of the international languages, plays an important role in international communication. It is used as a tool for international communication in many fields such as transportation, commerce, banking, tourism, technology, diplomacy, and scientific research (Brown, 2004). English is the official language for 45 countries in the world. One third of the world population speaks English and $75 \%$ of the television programs are produced in English. 95\% of the United Nations conferences and meetings are conducted in English and $80 \%$ of information on internet is presented in English (Wang, 2006). Based on the importance of English as a tool in the development of the country, both for international relations and scientifictechnological advancement, English was chosen by policy makers in Ethiopia as a foreign language to be taught in schools nationwide.

In the Ethiopian curriculum, there are four major skills (listening, speaking, reading, and writing) which have to be taught during the teaching and learning process. Although all four skills are important, speaking skill could be seen as the paramount skill during the English learning process. During the learning process, learners need to communicate with others in order to express their ideas and feelings. One of the ways to communicate with others is through speaking. Richards (2008) stated the mastery of speaking skills is a priority for second language learners. As a consequence, the effectiveness of an English course is decided based on how well the learners improve their spoken language proficiency. 
Assessment is an activity that engages both students and teachers in judgment about the quality of students' achievement or performance and inferences about the learning that has taken place (Sadler, 2005). Second language assessment is done either to measure a participant's actual level of competence or proficiency or to assess language development over a period of time (Bruton, 2009). There are few opportunities to evaluate students' speaking skills, because speaking assessment is not administered in any formal exam.

The curriculum and formal examinations focus heavily on grammar, but the speaking skill assessment is left entirely to the discretion of teachers. Hence, with the curriculum focus on this, in practice, English education in secondary schools puts a greater emphasis on English grammar, rather than speaking proficiency. Teacher-based classroom assessment as well as curriculum emphasizes enhancing oral communication skills. However, classroom assessment is not widely practiced in many Ethiopian secondary schools, even though for many students in Ethiopia, classroom assessment is the only opportunity to have their speaking skills assessed. Assessment of speaking skills indeed often lags far behind the importance given to teaching those skills in the curriculum (Knight, 1992). Teaching methodology goes hand in hand with the curriculum impact. Teachers simply spend too much time lecturing while students take notes and seldom participate in class (Tirualem, 2003).

In other words, even if the rationale for classroom assessment is to provide both students and teachers with information about their current level of speaking skills and how to improve their speaking skills on the basis of their real language performance, teachers are under pressure from the policy to reflect the result of classroom assessment as a certain portion or percentage of the students' final grades. So, the basic features of classroom speaking assessment present in the situation where it is expected to achieve both pedagogic usefulness and meet the desired measurement purpose.

The success of speaking is measured by the ability of students to carry out conversation in an interactive process of constructing meaning that involves producing, receiving and processing information. Likewise, Brown (2004) believed that language proficiency is ensured when learners get the opportunity to work with the target language in different contexts. Also, the study explores whether the current practice of classroom assessment in selected Wolaita Zone preparatory schools can be effective in terms of assessing speaking skill. Thus, investigating on the assessment of students' speaking skill is the main concern of this study.

As it can be understood from the foregoing discussion, the teaching of speaking skill and its assessment are very interrelated. The information obtained from the assessment of speaking skill can be used by teachers to improve their teaching of speaking skill. Besides, students can use the results of speaking assessments to improve their speaking ability. That is, the assessment of speaking skill can enhance students' speaking skill by showing areas and components to be improved by the students. Accordingly, assessment plays a pivotal role in the teaching and learning of speaking skill. That is why scholars argue that the teaching and assessment of speaking are seen as two sides of the same coin.

Despite this fact, speaking skill has not been properly and adequately assessed by English language teachers. From the experiences of teaching English at secondary and preparatory schools for the last eight years, the researchers have observed that teachers do not give due attention to the assessment of students' speaking skill. Such practice hinders students from getting important and necessary feedback and comments from their teachers. In other words, students do not get the needed feedback and comments from their English language teachers that may enable them to improve or enhance their speaking skill.

Besides, the extent to which English language teachers assess the speaking skill of their students is not clearly known. The assessment techniques used by English language teachers to assess the speaking skill of their students and the components of students' speaking skill assessed by English language teachers are not studied at the selected school. In addition, English language teachers usually encounter different challenges while assessing the speaking skill of their students. These problems have initiated the researcher to conduct a study on the present study. Accordingly, it is imperative to describe the practices and challenges of assessing the speaking skill of the students.

The other important rationale for the present study is that the research gap is observed in the area. That is, the review of local studies revealed that limited local studies were undertaken in relation to the present study. For instance, Fasil (1992) studied how oral skills are taught. Tsegaye (1995) conducted research on speaking strategies employed by college students respectively. Jenenew (2006) studied how oral skills are taught and also made a survey on teachers' and students' respective roles for implementation in EFL speaking classrooms. Tesfaye (2007) researched communication strategies utilized by Omo TTI teachers in oral production of English. Taye (2008) made a comparative study of televised and non-televised speaking skills teaching techniques.

However, the above studies do not examine the extent to which (Frequency) English language teachers assess the speaking skill of their students. The assessment techniques used by English language teachers to assess the speaking skill of their students have not been studied, so far as the researchers' knowledge is concerned. Furthermore, the challenges encountered by English language teachers while assessing the speaking skill of their students are not addressed by the aforementioned local studies.

Thus, specifically the objectives of the study are to examine the extent to which English language teachers assess the speaking skill of their students, and reveal the challenges encountered by English language 
teachers while assessing the speaking skill of their students.

\section{METHODOLOGY}

The study employed a descriptive research design. According to Best and Kahn (2003) descriptive research design enables the researcher to examine the present situation and identify some of the major problems in the area of the study. In line with this, descriptive design was used to describe the extent to which (Frequency) English language teachers' assess the speaking skill of their students. In addition, research designs are usually structured and specifically designed to measure the characteristics illustrated in a research question. It is also used to portray an accurate event and situations (Hair, et.al 2003). Accordingly, descriptive research design is used to clearly identify and describe the assessment techniques used by English language teachers to assess the speaking skill of their students. Besides, it is used describe the component of students speaking skill assessed by English language teachers. Furthermore, descriptive research design was used to point out the challenges encountered by English language teachers while assessing the speaking skill of their students.

\section{Participants of the Study}

This study was intended to investigate the assessment of students' speaking skill in some selected preparatory schools. Thus, English language teachers and students were selected as the major participants of this study. This is because it was believed that they can provide necessary data for the study. As stated above, the study was conducted in three schools (Shanto, Boditti, and Gacheno). In these three schools, there were 6 English language teachers who were teaching grade 11 students.

The target populations of this study are grade 11 preparatory school students and English language teachers of 2010 academic year. Accordingly, there were 150 students in Shanto Secondary and Preparatory School, 346 students in Boditti Secondary and Preparatory School and 200 students in Gacheno Secondary and Preparatory School. Totally, there were 696 students in the three schools. Only grade 11 students were taken as the participants of the study because it is believed that they can provide the data needed for the study. Samples were selected from the target population using different sampling techniques described in the next subsection

\section{Sample Size and Sampling Techniques}

Based on the information obtained from the record office of the schools, there were 696 students attending their class in 13 sections. Considering each section with an assumption that may have a different learning experience, the researcher selected 254 students by using Yemane's (1996) formula: $n=\frac{N}{1+N(e)^{2}}$ by using simple random sampling technique. Two hundred-fiftyfour students were selected as a sample population for the study by using simple random sampling technique. Besides, all six of the English language teachers who were selected availably as participants of the study teach grade 11 students.

\section{Data collection}

The data were gathered through questionnaire, interview, and classroom observation. Besides, the tools were pilot tested, in Boditti, in order to check the clarity of questions to the respondents. It was also intended to check the appropriateness and relevance of the instruments to achieve the purposes of this research. Based on the results of the pilot study, necessary changes and modifications were made on the tools of data collection and finally, the tools were used to collect data for the main study.

Questionnaire enables a researcher to collect the data from group of individuals within a short period of time (Kothari, 2004). It was developed based on the basic questions and on the available literature. The questionnaire contains both close-ended and open ended items. It was used to gather data from sampled students, triangulate the data obtained from the interview and classroom observation.

The questionnaire contains 4 subparts. The first sub part is intended to collect the background information of the participants. The second subsection was used to identify the extent to which English language teachers' assess the speaking skill of their students. The third sub section is meant to identify the assessment techniques used by English language teachers to assess the speaking skill of their students. Further, the fourth subpart is used to examine the component of students' speaking skill assessed by English language teachers. The last part collects information about the challenges that affect the assessment of speaking.

The researchers also used interview as a widely used instrument to collect qualitative data that allows the researchers to obtain firsthand information directly from participants (Burns 1999). Besides, semistructured interview was used to obtain firsthand information directly from some participants (Kumar, 2005).Semi-structured interview was used; hence the researcher can obtain firsthand information directly from some participants (Kumar, 2005). Therefore, semistructured interview was designed to obtain necessary data from the sampled English language teachers. The interview was used to triangulate the data obtained from the questionnaire and classroom observation. The researchers prepared five major parts pertaining to the objectives of the study. The first sub part is intended to collect the pertinent demographic, about participant teachers of the study. The second part is intended to examine the extent to which English language teachers' assess the speaking skill of their students in their EFL classroom. The third sub section is meant to identify the assessment techniques which used by English language teachers to assess the speaking skill of their students. Further, the fourth subpart is meant to describe the component of students' speaking skill 
assessed by English language teachers. Finally, the interview was used to point out challenges encountered by English language teachers' assessment of students' speaking skill.

The interview items were prepared based on literature review. Thus, six English language teachers were interviewed. The interviews took place face-toface and one interview meeting was used with one teacher only. The interactions were tape-recorded and played back during data analysis. Then, the recorded data were transcribed for analysis.

Finally, classroom observation was carried out to search out what is happening in actual classroom situation (Kumar, 2005). Classroom observation is also a powerful tool for getting insights into situations (Kothari, 2004). In this situation, Merriam (1998) also believed that classroom observation is a kind of data triangulation in order to validate the findings. Classroom observation provides the researcher opportunity to search out what is happening in actual classroom situation (Kumar, 2005). Besides, classroom observation is a powerful tool for getting insights into situations (Kothari, 2004).As the result, in this research, classroom observation used to crosscheck whether teachers and students have positive perceptions in the actual classroom situations.

Data collection from classroom observation took over two month's period beginning with classroom observation of six teachers and their lessons, three times each. The classroom observation was made in order to check whether or not English language teachers assess speaking skills in the actual classroom situation.

The observation was made based on a prepared notebook. The observer's notebook was prepared based on the objectives of the research and in line with literature review. The self-prepared observer's notebook assesses issues comprising the frequency that teachers to assess speaking skill. Besides, data were gathered in the form of note taking to see how English language teachers assess the speaking skills of the students.

To conduct the classroom observation, first the researcher asked permission and knew the schedule of the teachers. Then, the researcher observed the overall situation of the classes. During the classroom observation, the researchers sat in the class and took short notes to record how teachers assess students' speaking skill in the actual classroom situation. Moreover, those teachers teaching in their actual classroom situation were observed to get data on how
English language teachers assess the speaking skill of their students.

\section{Methods of Data Analysis}

The data gathered through questionnaire, interview, and classroom observation were analyzed differently using both qualitative and quantitative methods. For example, data obtained from interview were transcribed and transformed into textual data. The transcribed data were read again and again in order to have a full understanding of the themes the objectives of the study. The data that were relevant to achieve the purpose of this study were selected for analysis. The selected data were categorized according to related themes. In the end, the thematic categories were analyzed through description using words and summarized and paraphrased descriptively. Besides, the thematic analysis was supported by directly quoting the responses of the respondents. Then, the interview data was substantiated by questionnaire and classroom observation.

Regarding the data collected via questionnaire, first the questionnaires were checked for consistency and complete. The complete and consistent questionnaires were coded and filled in to SPSS. Then, different statistical analysis such as frequency and percentage was applied to SPSS data. The result of statistical analysis was presented in the table, pie chart and graph forms.

Finally, it was used to validate and substantiate the interview and questionnaire. Concerning the data collected through classroom observation, the raw data gained from classroom observation was tallied. Then, the obtained result was used to reveal the classroom practices of teachers in assessing the speaking skills of the students. The data was also used to validate and substantiate the data obtained via questionnaire and interview. During analysis, results obtained from questionnaires, interview and classroom observation were presented interactively in the way they and can support and validate each other.

\section{RESULTS AND DISCUSSIONS The Extent of Assessing Speaking Skills}

The extent to which teachers assess the speaking skill can determine the amount of feedback students get from the result of speaking assessment. Thus, it is important to know how often teachers assess the speaking skill of their students. The learners' response is demonstrated in the pi chart below. 


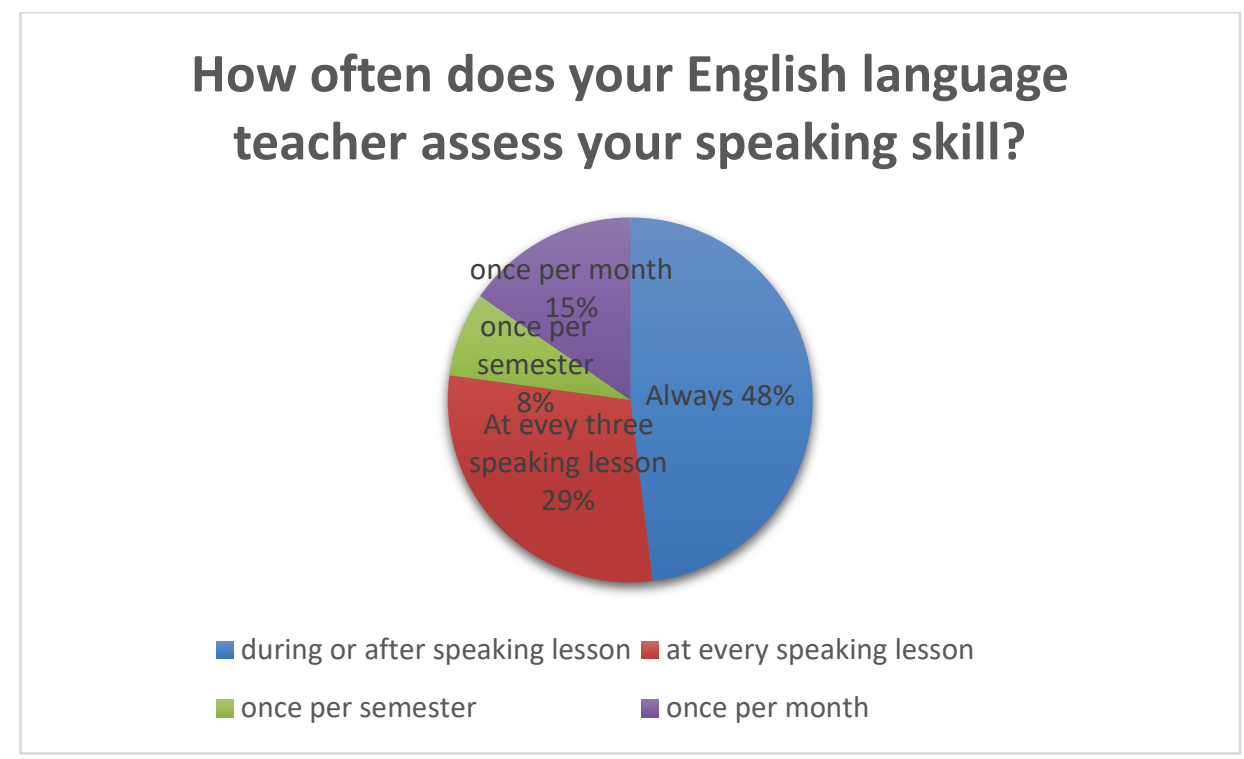

Figure 1. Frequency of Assessing Speaking Skills

Figure 1 reveals that among the study population, 48\% of the students reported that their English teachers assess their speaking skill during or after speaking lesson. In addition, $29 \%$ of the respondents said that at every three speaking lesson. However, 15\% and $8 \%$ responded that one per month and once per semester respectively. From this data, it can be concluded that most of the respondents replied that their English teacher always assess their speaking skill. However, considerable number of students reacted that their teachers assess their speaking skills in every three lesson, once per month and even once per semester.

The result of classroom observation reveals that two teachers were observed while assessing students' speaking skill using various kinds of techniques genuinely. From them, one teacher gave home take assignment to practice a certain topic, depending on their interest. The day of observation was presentation day, which students had experienced performing on various issues, at the end of every month, formally. The second teacher assessed his students' speaking skill in the same fashion. In addition to that, he told a story for the students and let them retell the same story in their own language, in front of their classmates. Every fifteen days they have experience in presenting a different technique. However, the rest of the teachers did not practice formal assessment effectively in the actual classroom situation. Rather, they assess their students informally, by oral questioning and answering. Assessment takes place during or at the end of the class every day.

From the results of questionnaire, interview, and classroom observations, it can be inferred that English teachers assess the speaking skill of their students at different times. But, it should be noted that majority of students and teachers reported that English language teachers assess speaking skill during speaking lessons. This may imply that teaching and assessment are interactively practiced by the teachers in the sampled schools.

The result coincides with Bachman (2010) and Cohen (2001) who disclosed that EFL teachers are continuously assessing the speaking skill during speaking lessons. This will be useful for both teachers and students. In addition, it would enable students to get feedback from their teacher. On the contrary from the literature, the response of teachers reveals that teachers' assessment of speaking skill is not uniformly undertaken by teachers as some teachers don't assess their students' speaking skills regularly.

\section{Classroom Time of Assessing Speaking Skills}

The research also checked the time spent in the classroom to assess students' speaking skills. The results are presented in Figure 2. 


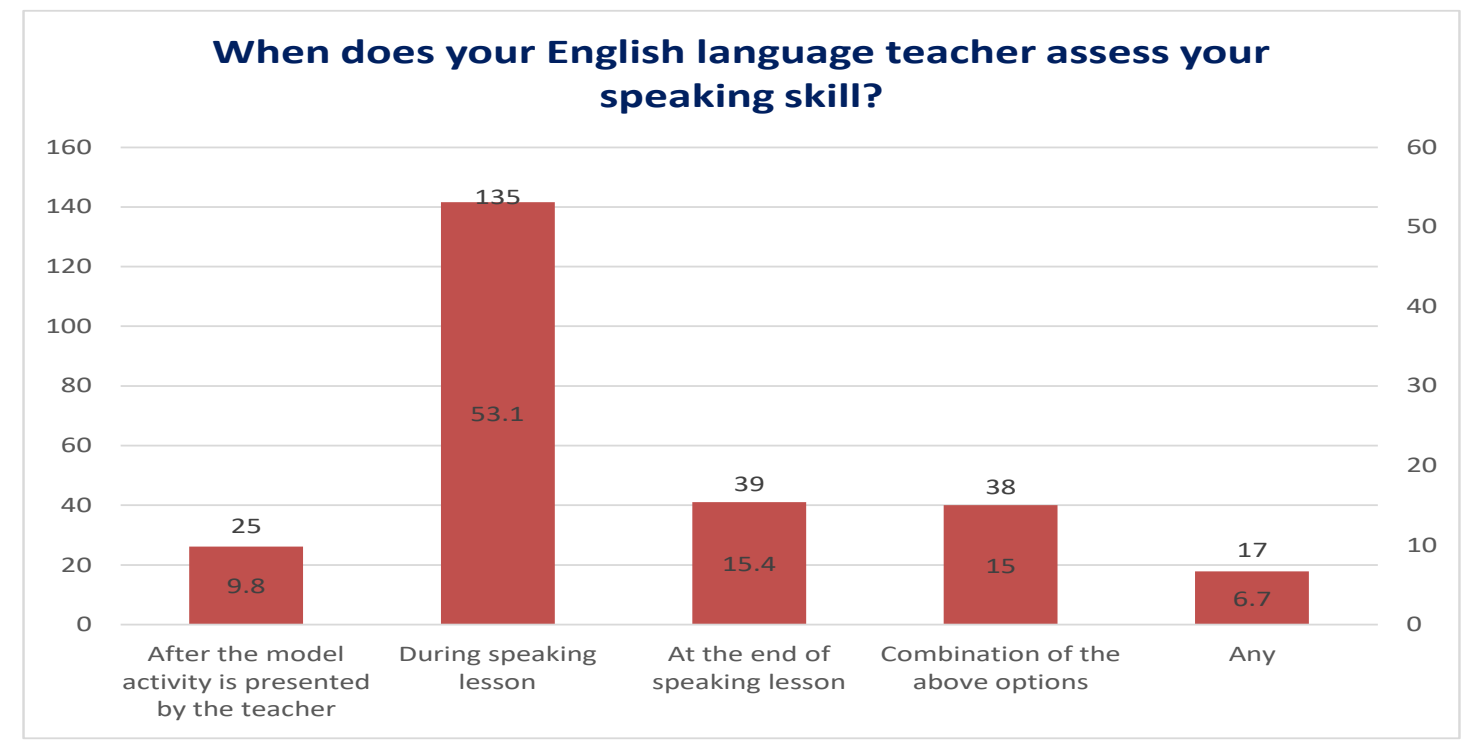

Figure 2: Classroom Time of Assessing Speaking Skills

As depicted in figure 2, 25(9.8\%) of students replied that their English language teachers assess their speaking skill after the model activity is presented by the teacher. In addition, $135(53.1 \%)$ of the respondents stated that their teacher assesses their speaking skill during the speaking lesson. However, 39(15.4\%) and $38(15 \%)$ of the students reported that their teachers assess at the end of speaking lesson and combination of the above options respectively. Hence, it can be concluded that a majority of the respondents said that their teachers assesses their speaking skill during speaking lesson.

Besides, teachers were asked when they assess the speaking skill of their students. They forwarded three different views. One group of teachers (T5, T6 and T2) reported that they assess their students' speaking lesson during the speaking lesson. In regards to this, T2 explained that "I assess informally during my lessons. Every lesson is unique." The second view is at the end of the speaking lesson, which was supported by T3 and T1).

Scholars like Harmer (2001), Jenenew (2006) and Luoma (2004), EFL teachers are expected to assess their students speaking skills uniformly during the speaking class. Specifically, speaking assessment should be done after delivering a model conversation or input to students. This helps students to be creative enough to bring the given input to the actual context. However, in the above graph, though each time has got distribution of the respondents, the dominant figure was displayed in "During speaking lesson". This trend should be revisited by EFL teachers in line with the existing scholarly views.

\section{Challenges that Teachers Encounter while Assessing the Speaking Skill of Students}

The next thing investigated is the challenges that teachers face during the assessment of their students' speaking skills. The results are presented in Table 4. 
Table 1. Students' Responses regarding the Challenges that Teachers Encounter while assessing the Speaking Skill of Students

\begin{tabular}{|c|c|c|c|c|c|c|c|c|c|}
\hline \multirow{3}{*}{ No } & \multirow{3}{*}{ Items } & \multicolumn{8}{|c|}{ Responses } \\
\hline & & \multicolumn{2}{|l|}{ Yes } & \multicolumn{2}{|l|}{ No } & \multicolumn{2}{|c|}{ Not Sure } & \multicolumn{2}{|l|}{ Total } \\
\hline & & $F$ & $\%$ & $\mathbf{F}$ & $\%$ & $\mathbf{F}$ & $\%$ & $\mathbf{F}$ & $\%$ \\
\hline 1. & $\begin{array}{l}\text { Do you think that assessing the } \\
\text { speaking skills of students is time } \\
\text { consuming? }\end{array}$ & 135 & 53.1 & 98 & 38.6 & 21 & 8.3 & 254 & 100 \\
\hline 2. & $\begin{array}{l}\text { Do you think that the availability of } \\
\text { adequate time affect the assessment } \\
\text { of speaking skill? }\end{array}$ & 128 & 50.4 & 99 & 39.0 & 27 & 10.6 & 254 & \\
\hline 3. & $\begin{array}{l}\text { Do you think that your school has } \\
\text { sufficient materials (textbook, } \\
\text { reference books, English lab class, } \\
\text { audio materials) that help to assess the } \\
\text { speaking skills of students? }\end{array}$ & 125 & 49.2 & 99 & 39.0 & 30 & 11.8 & 254 & 100 \\
\hline 4. & $\begin{array}{l}\text { Do you think that the number of } \\
\text { students affect the assessment of } \\
\text { students' the speaking skills? }\end{array}$ & 128 & 50.4 & 103 & 40.6 & 23 & 9.1 & 254 & 100 \\
\hline 5. & $\begin{array}{l}\text { Are you voluntary to have your } \\
\text { speaking skill assessed by your } \\
\text { teacher? }\end{array}$ & 184 & 72.4 & 44 & 17.3 & 44 & 17.3 & 254 & 100 \\
\hline 6. & $\begin{array}{l}\text { Teacher's way of assessing speaking } \\
\text { skill affects the assessment of } \\
\text { speaking skill? }\end{array}$ & 137 & 53.9 & 80 & 31.5 & 37 & 14.6 & 254 & 100 \\
\hline
\end{tabular}

Table 1 summarizes students' responses on the challenges that teachers encounter while assessing the speaking skill of students. Accordingly, in item I, students were asked if they think that assessing the speaking skills of students is time consuming. In the table, 135 (53.1\%) of students responded that assessing speaking skill of fellow students is time consuming. But, 98 (38.6\%) of the students reported no, and $21(8.3 \%)$ were unsure if assessing speaking skill is time consuming. Thus, the majority of students felt that assessing speaking skill of fellow students is time consuming. In item 2, majority of the respondents stated that availability of adequate time affect the assessment of students' speaking skill. Besides, the data obtained from interview and observation revealed that availability of adequate time is the main factor that affects the assessment of students' speaking skill.

Item 3 shows that majority of students and teachers replied lack of sufficient materials such as text book, reference books, English lab class, audio materials affect the assessment of speaking skill. During the researcher's observation, only one school which has ELIC Room even though it does not have sufficient materials that help to assess speaking. Due to this, none of the teachers from grade eleven used ELIC room. The rest schools also lack authentic materials which support the assessment of students speaking skill.

Regarding the influence of the number of students, $128(50.4 \%)$ of the respondents replied that the number of students affect the assessment of students' the speaking skills. However, $103(40.6 \%)$ of them reported no. The remaining responded, $23(9.1 \%)$ were unsure.
With this regard, all teachers agreed that the number of students affects the assessment of the students' speaking skill. For example, in interview, one teacher said, "Yes, it is impossible to effectively assess more than 15-20 students in 40 minutes. More time is required for more students. If I spend multiple days assessing my students' speaking, they will fall behind schedule in other areas."

As depicted in item 5, students were asked if they are voluntary to be assessed by your teacher. In response, $184(70.4 \%)$ said yes, $44(17.3 \%)$ said no, and $44(17.3 \%)$ were unsure. Hence, majority of the students are volunteers to be assessed by their teacher. In connection to this, five teachers reported that their students are voluntary to be assessed. For instance, one teacher said, "Yes, they are volunteer to participate in speaking activities, however, there are several affections, such as background language deficit, lack of adequate time, and required materials." However, another teacher said students are not voluntary to be assessed. Thus, though majority of students and teachers stated that students are voluntary to be assessed, considerable number of students and teachers reacted against this view. Beside, during classroom observation the majority of the students have stage phobia to be assessed in front of their classmate due to this they keep silent in the classroom and unable to generate speech. This implies that even if students volunteer to speak, they lack the necessary knowledge to produce speech in front of their classmates, for the purpose of assessment.

Finally, students were asked if way of assessing speaking skill affect the assessment of speaking skill. In 
response, 137 (53.9\%) said 'yes', 80 (31.5\%) said 'no', and $37(14.6 \%)$ were 'unsure'. Thus, majority of students felt that their teacher's inappropriate way of assessing speaking skill affects the assessment of speaking skill. The researchers' observation revealed that teacher's inappropriate way of assessment affects students' speaking assessment. This implies that assessing students' speaking skill, by nature, requires professionalism from the teacher.

Regarding the challenges in assessing speaking skills, some authors forwarded points to be considered. For example, Nunan (2001), Shaaban (2001) and Thornbury (2005) mentioned challenges like material scarcity, shortage of time, teachers' competence and class size. The findings of the current study also agree with these challenges. In addition, the techniques EFL teachers use and students poor linguistic competence should also be considered according to the present study.

\section{CONCLUSION}

The study revealed that the majority of students and all of the teachers believe that assessment of speaking skill is important for its teaching. Thus, this clear understanding of teachers and students about the importance of speaking skill can facilitate teachers' assessment of students speaking skill. However, the actual classroom observation confirms, oral assessment in the actual classroom situation is not applicable as needed.

The majority of students and teachers believe that the assessment of students' speaking skill helps the students to improve their speaking skill. Hence, it can be said that speaking assessment can serve as a powerful motivation tool for the students to improve their speaking skill. The belief and the practice in the actual classroom situation are paradox about speaking assessment because both respondents believe the importance of speaking assessment, but it was not observed during classroom observation session. They are far behind from the reality to create exposure to let the students practice in the real classroom situations. The study revealed that English language teachers assess the speaking skill of students at different times. Besides, it was noted that majority of students and teachers reported that teachers assess speaking skill during speaking lesson. Classroom observation divulges that speaking assessment doesn't get genuine consideration.

There are challenges that teachers encounter while assessing the speaking skill. The result of the study divulged that the majority of students felt that assessing speaking skill of fellow students is time consuming. Besides, the majority of the respondents stated that availability of adequate time affect the assessment of students' speaking skill. This was clearly observed during classroom observation since teachers were facing difficulties to manage the allotted class time. The study also shows that the school schedule is not adequate to assess the speaking skill.

In addition, the majority of students and teachers replied lack of sufficient material affects the assessment of speaking skill. In addition, majority of students believe that lack of sufficient material affect the assessment on speaking skill. The responses of students are supported by the interview data. That is, all interviewed teachers reported that the schools have no adequate material and lack of the materials affect the assessment of speaking skill. Even though, the problem exists, students and teachers are not wise enough to use the resources in their surroundings. The researcher observed that some materials are wasted without giving proper service as needed.

The finding of the study shows that the majority of teachers and students reported that the number of students affect the assessment of students' the speaking skills. Researcher classroom observation confirms the same truth. Furthermore, the majority of students felt that teacher's inappropriate way of assessing speaking skill affect the assessment of speaking skill. The nature of assessing speaking skill requires professionalism. Some situations need immediate and perfect answers, and assessing in such situations may drive some teachers to be in confusion, lacking a proper response. This situation was observed frequently during classroom observation.

Finally, based on the conclusions it is recommended that teachers should be more rigorously trained in the assessment of speaking skill so that they are comfortable and proficient in the assessment. Large class size is found out be a hindrance to speaking assessment. Therefore, it is advised that the problem of large class sizes should be addressed in schools.

\section{REFERENCES}

Bachman. (2010). Language assessment in practice: Developing language assessments and justifying their use in the real world. Oxford: OUP.

Best, J. W., \& Kahn, J. V. (2003). Research in education (10th ed.). Boston: Allyn and Bacon Publishers.

Brown, H.D.. (2004). Language assessment principles and classroom practices. New York: Longman.

Brown, S., \& Knight, P. (1994). Assessing learners in Higher Education. London: Rutledge flamer.

Bruton, A. (2009). The vocabulary knowledge scale: A critical analysis of language assessment. Quarterly, 6(4), 288-29. Cambridge: CUP

Burns, A. (1999). Collaborative action research for English language teachers. Cambridge: Cambridge University Press.

Cohen, D.A. (2001). Second language assessment. In Celce-Murcia, M. (eds.) Teaching English as a Second or foreign language $\left(3^{\text {rd }}\right.$ ed.) (pp. 515534).Boston: Heinle \& Heinle/Thomson Learning.

Crooks, T. (1988). The impact of classroom evaluation practices on students. Review of Educational research, 58(4), 438-481.

Davison, C., \& Leung, C. (2009). Current issues in English language teacher-based assessment. TESOL Quarterly, 43(3 ), 393-415.

Fasil, D. (1992). Communicative Strategies Employed by Senior High School Students in Oral Production of English: MA Thesis. Addis Ababa University. 
Harmer, J. (2001). The Practice of English Language Teaching (Third Edition). London and New York: Longman Group.

Hair, J.F.J., Babin, B., Money, A.H., \& Samuel, P. (2003). Essentials of Business Research Methods. USA: John Wiley and Sons, Leyh Publishing, LLC.

JenenewBekele. (2006). Teachers' and students' role implementation in EFL speaking classroom; (MA Thesis). Addis Ababa University, Ethiopia.

Knight, B. 1992. Assessing speaking skills: A workshop for teacher development. ELT Journal, 46(3), 294-302.

Kothari, C. (2004). Research methodology. (2 $2^{\text {nd }}$ ed.). New Delhi: New Sage International Limited Publishers.

Kumar, R, (2005). Research methodology. London: SAGE Publications.

Luoma, S. (2004). Developing speaking tasks. assessing speaking. Cambridge. Cambridge University Press.

Merriam, S.B. (1998). Qualitative research and case study applications in education. San Francisco: Jossey-Bass

Nunan, D. (2001). Practical English language teaching. New York: McGraw Hill.

Richards, J.C. (2008). Teaching listening and speaking. From theory to practice. Cambridge: Cambridge university press.
Sadler, D. (2005). Second language assessment of evaluation in higher education. New York: Longman Group.

Shaaban, K. (2001). Assessment of young learners. English teaching forum, 39(4), 16-23.

Taye G. (2008). A comparative study of televised and non- televised speaking skills teaching techniques (MA Thesis). Addis Ababa University, Ethiopia.

Tesfaye, A. (2007). Communication strategies utilized by OmoTti trainee-teachers in oral production of English. (MA Thesis). Addis Ababa University, Ethiopia.

Thornbury, S. (2005). How to teach speaking. Pearson Harlow: Longman.

Tirualem, A. (2003). The classroom practice of learnercentered approach in second cycle primary school of Addis Ababa. (Unpublished Thesis). Addis Ababa University, Ethiopia.

Tsegay, T. (1995). Speaking strategies employed by first year students at the KotebeCollege of Teacher Education. (Unpublished Thesis). AAU, Ethiopia.

Wang, S. R. (2006). Promoting college English reform to improve the teaching quality of China's higher education, Foreign Language World, (5), 2-6.

Yamane, T. (1967). Statistics: An introductory analysis. 2nd Edition, New York: Harper and Row. 